\title{
Analysis on the Management Problems and Development Countermeasures of Farmers' Cooperatives in Dujiangyan City
}

\author{
Xueke Chen \\ Sichuan Agricultural University \\ Chengdu, China \\ Xia Chen \\ Sichuan Agricultural University \\ Chengdu, China
}

\author{
Dongchuan Lin* \\ Sichuan Agricultural University \\ Chengdu, China \\ Xiang Tan \\ Sichuan Agricultural University \\ Chengdu, China
}

\begin{abstract}
The farmers' Cooperative, as a new form of production organization, is an important channel to promote the development of the agricultural industry and the increase of farmers' income, it has promoted the development of modern agriculture. Combining with the actual investigation of the farmer specialized cooperatives in Dujiangyan of Sichuan province, this paper analysis on the current situation of the development of the farmer specialized cooperatives in Dujiangyan city of Sichuan province, found the problems existing in the management and management at the present stage, and puts forward countermeasures and suggestions to the development.
\end{abstract}

Keywords-financing; marketing; talent; democratic management

\section{INTRODUCTION}

China's national people's Congress adopted the law on farmers' specialized cooperatives on October 31, 2006, and implemented it on July 1, 2007. As one of the subjects in the market, the Farmers' cooperative has been legal since 2007. In 2015, research report on China's economic development shows that the overall development of cooperative economy in China is still fast, and more types of cooperative economic organization are making joint development. But cooperatives still cannot offer services to rural economy efficiently and build a well-off society due to their uneven development. In today's economic and social background, the research on management of rural economic cooperative organizations is particularly important.

\section{THE DEVELOPMENT SitUATION OF FARMERS' SPECIALIZED COOPERATIVES IN DUJIANGYAN}

Since 1988 to November 2014, the number of farmer specialized cooperative economic organizations has reached 375 , including 40 provincial and municipal demonstration agency, and that of the cooperatives' members has reached 4.82 million. These cooperatives drive 8.12 million farmers, accounted for $66.8 \%$ of the city's total rural households. Nearly three years of development in Dujiangyan as shown in "Table I".

The annual growth rate of the total number of cooperatives in 2014 is as two times or more as that of 2013, and the number of the members has increased nearly half, suggesting such a remarkable development and expansion of Dujiangyans' cooperatives. But serious internal polarization exists. At present, a minority of cooperatives such as "Dujiangyan Qingcheng Xingnong tea", "Dujiangyan City high Fengzhu" have developed well, while others have run into limited scales, such as "Dujiangyan Jinpeng seedlings planted". In terms of the healthy development and steady growth of farmers' cooperatives, to promote the scale and standardization of modern agriculture in Dujiangyan and to improve the management are urgent problems.

TABLE I. THE DEVELOPMENT SITUATION IN RECENT 3 YEARS

\begin{tabular}{|c|c|c|c|c|c|c|c|c|}
\hline Year & Total & Growth Rate & Demonstration Agency & Growth Rate & Member & Growth Rate & Provincial and municipal model & Growth Rate \\
\hline 12 & 170 & & 61 & & 11190 & & 16163 & \\
\hline 13 & 225 & $32 \%$ & 78 & $28 \%$ & 12824 & $15 \%$ & 16779 & $4 \%$ \\
\hline 14 & 375 & $67 \%$ & 94 & $8 \%$ & 18237 & $42 \%$ & 81205 & $402 \%$ \\
\hline
\end{tabular}

This paper is supported by the general project of the Sichuan Center for Rural Development Research in 2015 (NO.CR1510), by the general project of the Sichuan Center for Liquors Development Research in 2015 (NO.CJY15-06), by student's innovation training project of Sichuan Agricultural University in 2016(no: 201610626103), and by eighth level funding of discipline construction "double program" of Sichuan agricultural University in 2016.

*Corresponding author: Dongchuan Lin
III. THE PROBLEMS OF FARMERS' PROFESSIONAL COOPERATIVES IN DUJIANGYAN

This paper selects 18 representative demonstration specialized cooperatives as the total sample, respectively, 
analyzing from two aspects - the management and ordinary members.

\section{A. Financing Channels}

Currently, the financing of cooperatives in Dujiangyan primarily relies on capital injection by the shareholders.
Farmers would like to inject agricultural machinery, land use rights and other physical capital, without full use of financial leverage tools - borrowing. The amount of funds invested by the farmers' cooperatives is relatively limited. The proportion of financing channels is as follows "Table II" :

TABLE II. PROPORTION OF FARMERS' COOPERATIVE FINANCING TABLE (MILLION YUAN)

\begin{tabular}{ccccc}
\hline & $\begin{array}{c}\text { Core shareholders } \\
\text { Stakes }\end{array}$ & $\begin{array}{c}\text { Bank } \\
\text { Borrowings }\end{array}$ & Personal Borrowings & Sector financing \\
\hline The amount Of financing & 4382 & 643 & 584 & 234 \\
Total Financing & 5842 & 5842 & 5842 & 5842 \\
The proportion & $75 \%$ & $11 \%$ & $10 \%$ & $4 \%$ \\
\hline
\end{tabular}

Financial funds from core shareholder accounted for $75 \%$ of the total financing funds, bank loans and private borrowing only accounted for $10 \%$ of the total funds, and agricultural subsidies accounted for less than $5 \%$. This proportion caused by small scale of cooperatives, which miss the financial institution lending requirements, by the looseness of structure, which is difficult to obtain loans, and by the lack of collateral assets, which result in collateral loan is not practical. Therefore, the shortage of funds is limited to expand the scale, to introduce new technology and talent, and to establish marketing channels.

\section{B. Marketing Methods}

Dujiangyan city farmers' professional cooperatives did not carry out a series of marketing plan to increase the sales amount, lacking of diversified sales channels "Table III", "Table IV".

TABLE III. MARKETING METHODS

\begin{tabular}{|l|l|l|l|}
\hline \multicolumn{1}{|c|}{ Marketing Methods } & \multicolumn{1}{|c|}{ Wholesale } & \multicolumn{1}{|c|}{ Retail } & \multicolumn{1}{c|}{ Network Sales } \\
\hline Sales amount & 10,754 & 12,507 & 1,829 \\
\hline Total sales amount & 25,090 & 25,090 & 25,090 \\
\hline The Proportion & $43 \%$ & $50 \%$ & $7 \%$ \\
\hline
\end{tabular}

TABLE IV. PROMOTION WAYS

\begin{tabular}{|l|l|l|l|l|}
\hline \multicolumn{1}{|c|}{$\begin{array}{c}\text { Promotion } \\
\text { Ways }\end{array}$} & Media & Billborard & $\begin{array}{c}\text { Network } \\
\text { Promotion }\end{array}$ & $\begin{array}{c}\text { Customer } \\
\text { Promotion }\end{array}$ \\
\hline $\begin{array}{l}\text { Implemented } \\
\text { cooperatives }\end{array}$ & 3 & 7 & 4 & 18 \\
\hline $\begin{array}{l}\text { Total } \\
\text { cooperatives }\end{array}$ & 18 & 18 & 18 & 18 \\
\hline The Proportion & $16.67 \%$ & $38.89 \%$ & $22.22 \%$ & $100 \%$ \\
\hline
\end{tabular}

On the "brand" investment, the recovery period is relatively long. According to the survey on brand awareness of farmers, nearly $50 \%$ of the farmers did not pay attention to brand building. In the remaining farmers, only two cooperatives advertised by the media (interview by Dujiangyan reporters), 7 cooperatives by roadside billboards (located near 1000 meters because of limited funds), and most of the cooperatives mainly rely on the promotion by old customers to maintain sales, having a certain effect limited to the surrounding villages and towns. For network promotion, only 4 began to involve it slightly in the past two years. Wholesale and retail is the main sales model. The amount of sales by retail is greater than that by wholesale, suggesting that main sales crowd is near the township area, which restricted the development of the professional cooperatives of farmers.

\section{Talent Shortage}

The lack of local talent mainly results from the low income and low education levels. The state has implemented the plan of driving agriculture by industry and of driving rural areas by urban since 2007. However, in terms of the current development of farmers' specialized cooperatives in Dujiangyan, the growth rate of actual income of farmers increased more slightly than that of urban residents. Furthermore, accounting for at least eighty percent of the total members, farmers are lack of education and cooperation awareness. Coupled with the aging population and other problems, it leads to the shortage of talent. With the living conditions getting better and better, young people are not willing to engage in agriculture. The difficulties showed above negatively impact development of cooperatives, even of rural economic.

\section{The Democratic Management}

After polling 40 households, the survey point out that only 2 of the respondents admitted the democratic management in the cooperatives.

The farmer specialized cooperative should be the one which is set by people, managed by people and beneficial to people. Most shareholder of cooperatives in the sample are made up of relevant government departments and individual business, which absolutely controlled and dominated the organizations, and farmer shareholders accounted for considerably less shares, having no rights. The quality of management does not affect farmers' income. The product won't benefit farmers obviously, no matter it sold well or not in the market, even with cooperatives' help, because such a small scale of the cooperatives is hard to generate substantial benefits for farmers. So, concerning these situations, we can conclude that major shareholders only care about their own interests, ignoring the vital interests of farmer members in reality, and that local cooperatives haven't brought into play its function. 


\section{E. Common Problems in Dujiangyan's Farmers' Cooperative's Management}

1) Preferential policies are not implemented well: The Party Central Committee and the State Council have implemented strategy about restructuring the agriculture to accelerate the transformation of the agricultural development mode, and have introduced a series of relative policies. The government of Dujiangyan has also developed some measures to support the development of farmers' specialized cooperatives, such as agricultural policy insurance subsidies whose maximum reached $90 \%$ of the original cost, the agricultural purchasing subsidies whose maximum reached 250 thousand yuan, certification awards whose maximum reached 3 millions yuan each time, and poverty alleviation which up to 450 thousand yuan each village.

2) Operating mechanism of majority "organizations" is not standard: In Dujiangyan, the loose farmers' cooperatives are much more than close ones, and the technical service cooperatives are more than production and operation ones. There are less activities in some cooperative's and no specific cooperation, for example, Dujiangyan E Fu rich peasants bamboo shoots cooperative has a meeting one or a half year a time, hold a training once more than 1 year "Table V", "Table VI":

TABLE V. FREQUENCY OF FARMERS' COOPERATIVE ORGANIZATION GENERAL MEETING

\begin{tabular}{|c|l|l|l|}
\hline & $\begin{array}{c}\text { Once Six } \\
\text { months or } \\
\text { less }\end{array}$ & $\begin{array}{c}\text { Once Six } \\
\text { months } \\
\text { To one year }\end{array}$ & $\begin{array}{c}\text { Once More } \\
\text { Than one } \\
\text { year }\end{array}$ \\
\hline $\begin{array}{c}\text { Implemented } \\
\text { cooperatives }\end{array}$ & 5 & 9 & 4 \\
\hline $\begin{array}{c}\text { Total } \\
\text { cooperatives }\end{array}$ & 18 & 18 & 18 \\
\hline The Proportion & $28 \%$ & $50 \%$ & $22 \%$ \\
\hline
\end{tabular}

TABLE VI. FREQUENCY OF FARMERS' COOPERATIVE ORGANIZATIONS TECHNICAL TRAINING

\begin{tabular}{|c|l|l|l|}
\hline & $\begin{array}{c}\text { Once Six } \\
\text { months or less }\end{array}$ & $\begin{array}{c}\text { Once Six } \\
\text { months } \\
\text { To one year }\end{array}$ & $\begin{array}{c}\text { Once More } \\
\text { Than one year }\end{array}$ \\
\hline $\begin{array}{c}\text { General } \\
\text { meeting }\end{array}$ & 3 & 7 & 8 \\
\hline $\begin{array}{c}\text { Technical } \\
\text { training }\end{array}$ & 18 & 18 & 18 \\
\hline $\begin{array}{c}\text { Technical } \\
\text { training }\end{array}$ & $17 \%$ & $39 \%$ & $44 \%$ \\
\hline
\end{tabular}

Most cooperatives are loose, and the members are mixed. Even though the frequency of meetings and training has reached the minimum, it is still difficult to align its members. Therefore, the cooperation of Farmers' specialized organizations is less effective. The cooperatives are lack of necessary support toward industrial development and economic entity. Their internal interests distribution system in which members should share the interests and risks equally is not sound. Such long-term mechanisms as Democratic management and supervision in decision are poor. Because of the small amount of members, limited scale and low service level, farmers specialized cooperatives are lack of motivation for self-development with poor overall quality.

\section{STRATEGIES AND RECOMMENDATIONS TO DUJIANYAN'S FARMERS' SPECIALIZED COOPERATIVE MANAGEMENT}

\section{A. Combining Financing Innovation and Financial Management}

The government can take advantage of local financial institutions to develop credit products based on characteristics of farmers' specialized cooperatives' demand. First of all, it can expand the scope of loans and streamline loan procedures, starting with receivables and land mortgage-backed and other methods. Secondly, banks can take Farmers' specialized cooperative credit rating and credit limit into their daily work to implement dynamic management with adjustment in a timely manner. Thirdly, the government should actively explore cooperation mechanisms to facilitate the Farmers' mutual benefits, combined with Farmers' specialized cooperatives, cooperative banks and insurance companies. Some cooperatives in Dujiangyan have no specialized financial institution or managers. So cooperatives need to train a team of professional financial managers familiar with the Farmers' cooperative business model and loose nature of the business, dealing with account of agricultural products and to introduce the financial disclosure system to improve finance credit of cooperatives, thereby getting the credit and reducing financing risks. Financing and financial management are equivalent to increasing revenue and cutting expenditure, combined with application to reduce problems due to the shortage of funds.

\section{B. Network Marketing Combined with Eco-tourism}

Local Farmers' specialized cooperatives can use WeChat, Taobao and some other network tools to popularize and sale their products rather than limit the sales channels to nearby towns. With the development of urbanization, more and more people like agro-ecological tourism. Farmers' cooperatives can be combined with it, involving urban residents in the cultivation and picking processes. For example, Dujiangyan Yu King Lotus Lake Kiwi Export Production Cooperative has a piece of specialized land provided for visitors to claim and culture. Visitors will pick fruit in the certain season, and cooperative's member can help them to care their land in the rest of the time. Both Ecotourism and Internet marketing are fresh marketing models to increase awareness, promote sales and increase revenue of Farmers' economic organization.

\section{Human Resources Management}

Developed and expanded farmers' specialized cooperatives have more financial and material resources and security to attract more talents. So human resource management is important for normal farmers' specialized cooperatives. They can set up an internal human resources department, establish the human resources management system, improve the ability to resist risks, and refine its 
management measures. They can introduce some talents who are familiar with farming technology and marketing knowledge, and recruit the youth who are interested in Farmers' specialized cooperative. They also can establish and strictly enforce a comprehensive reward and punishment system, enhancing the enthusiasm of its members, so that those loose Farmers' cooperatives are organically integrated.

\section{Limit Shareholders and Shares}

Refer to cooperative management principles in the United States, members of the farmers' professional cooperatives must come from agricultural producers. Member dues or shares are limited. Shares of each member shall not exceed $8 \%$ of the total capital of all members, which performed a good democratic management of Farmers' specialized cooperatives. But there are some differences about the national conditions in China. Farmers' specialized cooperatives in China can be set up with a stake limit after considering the reality. Each share is the symbol of claiming rights for cooperatives and shall not exceed the limit to prevent the emergence of sole majority shareholder and extreme internal control. According to the situation in Dujiangyan that the farmer fund of Farmers' specialized cooperatives relies on farming income and these cooperatives are lack of idle funds, the limit of shares of individual businesses or enterprises can be expanded to $20 \%$ $30 \%$. Furthermore, the government should step up the significance of joining cooperatives to encourage farmers to become shareholders.

\section{E. Improve the Internal Organizational Structure}

Local Farmers' specialized cooperatives should hold the general meeting of shareholders in accordance with laws and set up the board of supervisors, the Council and other functional departments. The general meeting of shareholders should be held regularly between 1 and 2 times a year to inform the cooperative working arrangements and the expected effects and to summarize the performance at the end of each year. When they are coming into emergency situations, temporary shareholders' meeting will be needed to make decisions democratically so that no individual member can be injurious to the overall interests of the cooperative. Internal control was a prominent problem in the past, because cooperatives were operated by several large shareholders. Most members did not hold shares for various reasons, so they no profit is distributed to them in the yearend distribution. In this case, profit distribution system shouldn't depend on a single line, but should take into account each farmer's total amount of patronage in this year. Based on sharing the interests and risks equally, farmers work closely with cooperatives, promoting healthy and steady development of cooperatives.

\section{REFERENCES}

[1] Chunrong Wang. The Research on governing mechanism of Agricultural specialized cooperatives [J]. Economic and Trade Update. 2012 (5).
[2] Gao Rui. Problems and Countermeasures Of Agricultural Cooperatives in China [J]. Home for you, 2012 (3).

[3] Wei wei. Beijing Farmers Vegetables Specialized Cooperative Innovation Management System[J]. Economic Research Guide, 2013 (9).

[4] Yanyan Guo. Study on the Problems and Countermeasures of Agricultural Cooperatives - the case of Taigu [J]. Journal of Shanxi Agricultural University (Social Science Edition), 2013,12 (3).

[5] Azzam A.and Andersson H.Measuring Price Effects of Concentration in Mixed Oligopoly:An Application to the Swedish Beef Slaughter Industry [J]. Journal of Industry, Competition and Trade, 2008,8(1):21-311. 